\title{
Record of Decision Remedial Alternative Selection for the Burma Road Rubble Pit (231-4F)
}

by

E. Palmer

Westinghouse Savannah River Company

Savannah River Site

Aiken, South Carolina 29808

DOE Contract No. DE-AC09-89SR18035

This paper was prepared in connection with work done under the above contract number with the U. S. Department of Energy. By acceptance of this paper, the publisher and/or recipient acknowledges the U.S. Government's right to retain a nonexclusive, royalty-free license in and to any copyright covering this paper, along with the right to reproduce and to authorize others to reproduce all or part of the copyrighted paper. 


\section{DISCLAIMER}

This report was prepared as an account of work sponsored by an agency of the United States Government. Neither the United States Government nor any agency thereof, nor any of their employees, makes any warranty, express or implied, or assumes any legal liability or responsibility for the accuracy, completeness, or usefulness of any information, apparatus, product, or process disclosed, or represents that its use would not infringe privately owned rights. Reference herein to any specific commercial product, process, or service by trade name, trademark, manufacturer, or otherwise does not necessarily constitute or imply its endorsement, recommendation, or favoring by the United States Government or any agency thereof. The views and opinions of authors expressed herein do not necessarily state or reflect those of the United States Government or any agency thereof.

This report has been reproduced directly from the best available copy.

Available to DOE and DOE contractors from the Office of Scientific and Technical Information, P.O. Box 62, Oak Ridge, TN 37831; prices available from (615) 576-8401.

Available to the public from the National Technical Information Service, U.S. Department of Commerce, 5285 Port Royal Road, Springfield, VA 22161. 


\section{DISCLAIMER}

Portions of this document may be illegible electronic image products. Images are produced from the best available original document. 


\section{United States Department of Energy}

Savannah River Site

\section{Record of Decision}

Remedial Alternative Selection

for the

Burma Road Rubble Pit (231-41?) (U)

" WSRC-RP-96-101

Revision 1

April 1996

Westinghouse Savannah River Company

Savannah River Site

Aiken, South Carolina 29808 


\section{DECISION SUMMARY \\ REMEDIAL ALTERNATIVE SELECTION (U)}

BURMA ROAD RUBBLE PIT UNIT (231-4?)

WSRC-RP-96-101

Revision 1

April 1996

Savannah River Site

Aiken, South Carolina

Prepared by:

$$
\begin{aligned}
& \text { Westinghouse Savannah River Company } \\
& \text { for the }
\end{aligned}
$$

U.S. Department of Energy Under Contract DE-AC09-89SRI 8035

Savannah River Operations Office Aiken, South Carolina 


\section{DECISION SUMMARY \\ TABLE OF CONTENTS}

Section

Page

I. Site and Operable Unit Name, Location, and Description

II. Operable Unit History and Compliance History

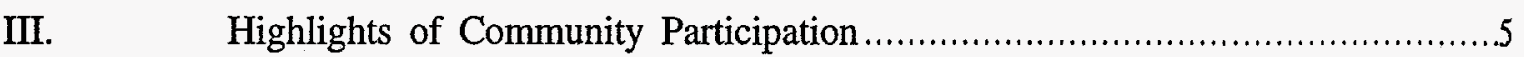

N. Scope and Role of Operable Unit Within the Site Strategy ................................

V. Summary of Operable Unit Characteristics.............................................. 8

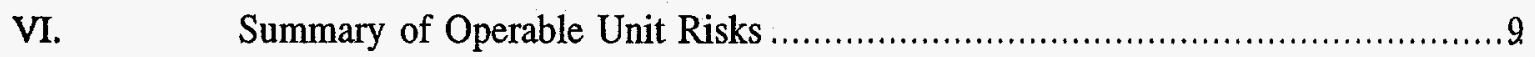

VH. Description of the No Action Alternative ................................................14

VIII, Explanation of Significant Changes ……...............................................14

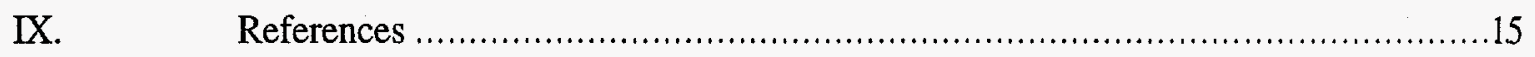

\section{List of Figures}

Figure 1: Location of the Burma Road Rubble Pit at the Savannah River Site .............2

Figure 2: $\quad$ Location of the Burma Road Rubble Pit Waste Unit .....................................

Figure 3: General Configuration of the Burma Road Rubble Pit ......................................

Figure 4: Burma Road Rubble Pit Regional Groundwater Flow Map (Second Quarter 1994).....

List of Tables

Anpendix

A. 


\section{DECLARATION FOR THE RECORD OF DECISION}

\section{Unit Name and Location}

Burma Road Rubble Pit unit (SRS Building Number231-4F)

Savannah River Site

Aiken, South Carolina

The Burma Road Rubble Pit (BRRP) unit (231-4F) is listed as a Resource Conservation and Recovery Act (RCRA) 3004(u) solid waste management unit/Comprehensive Environmental Response, Compensation and Liability Act (CERLCA) unit in Appendix C of the Federal Facility Agreement (FFA) for the Savannah River Site.

\section{Statement of Basis and Purpose}

This decision document presents the selected remedial action for the BRRP unit soils located at the SRS in Aiken, South Carolina. The selected action was developed in aecordance with CERCLA, as amended, and to the extent practicable, the National Oil and Hazardous Substances Pollution Contingency Plan (NCP). This decision is based on the Administrative Record File for this specific RCRA/CERCLA unit.

\section{Description of the Selected Remedy}

The results of the RCRA Facility Investigation/Remedial Investigation indicate that the BRRP unit soils pose minimal risk to human health and the environment. Therefore, no action is needed for the BRRP unit soils. Only non-hazardous, inert material (e.g., wood, trash, wire, bottles, plastic, rubble, foam, concrete, etc.) was placed at the BRRP source unit. A notation, identifying the presence of buried, inert debris, on the deed to the facility property will be placed in the Aiken County Records. This notation will include a survey plat, prepared and certified by a professional land surveyor, of the area. This is a final RCRA/CERCLA action for the BRRP unit soils.

Groundwater contamination beneath the BRRP is due to migration from upgradient sources and thus will not be addressed in this remedial action. Following an investigation on upgradient groundwater contaminant sources, a determination will be made as to what corrective action might be appropriate for the groundwater beneath the BRRP.

\section{Declaration Statement}

Based on the results of the remedial investigation, no action is necessary at the BRRP unit soils to ensure the protection of human health and the environment. Since the BRRP unit soils pose minimal risk to human health and the environment, and no action is needed, the CERCLA Section 121 requirements are not applicable. This action is protective of human health and the environment and is meant to be a permanent solution, final action, for the BRRP unit soils. Section 300.430(f)(4)(ii) of the NCP requires that a Five-Year Review of the Record of Decision be performed if hazardous substances, pollutants, or contaminants remain at the unit. The three Parties have determined that a Five-Year Review of the ROD for the BRRP unit soils will not be performed. The remedial action selected for this unit (No Action) results in no hazardous substances, pollutants, or contaminants remaining in the soils of the BRRP source unit. 


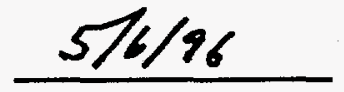

Date

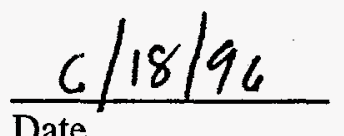

$\frac{7 / 8 / 96}{\text { Date }}$

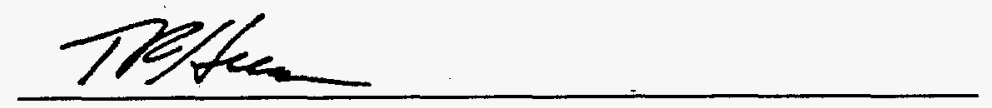

T. F. Heenan

Assistant Manager for Environmental Restoration and Solid Waste

U.S. Dept. of Energy, Savannah River Operations Office
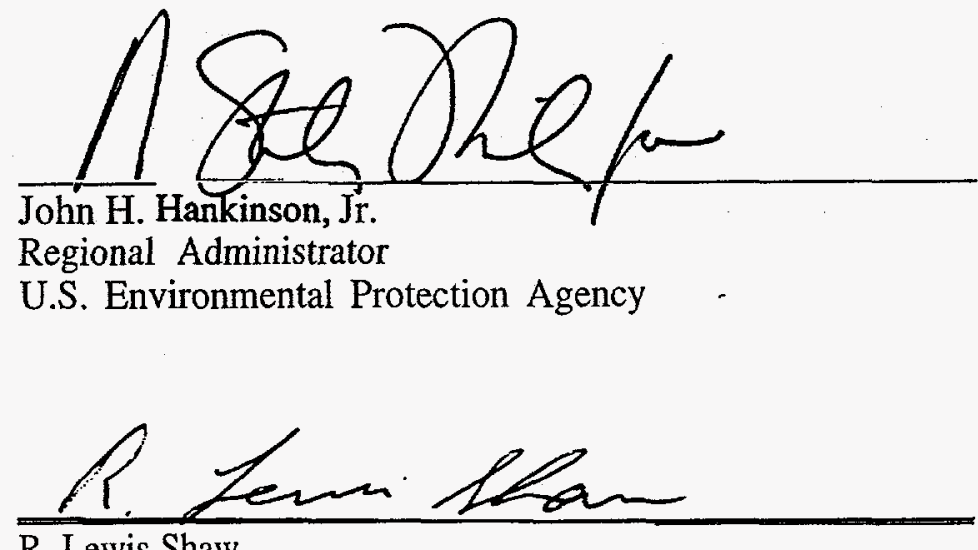

R. Lewis Shaw

Deputy Commissioner

Environmental Quality Control

South Carolina Department of Health and Environmental Control 


\section{Site and Operable Unit Name, Location, and Description}

The Savannah River Site (SRS) occupies approximately 310 square miles of land adjacent to the Savannah River, principally in Aiken and Barnwell counties of South Carolina (Figure 1). SRS is a secured U.S. Government facility with no permanent residents. SRS is located approximately 25 miles southeast of Augusta, Georgia and 20 miles south of Aiken, South Carolina.

SRS is owned by the U.S. Department of Energy (DOE). Management and operating services are provided by Westinghouse Savannah River Company (WSRC). SRS has historically produced tritium, plutonium, and other special nuclear materials for national defense. SRS has also provided nuclear materials for the space program and for medical, industrial, and research efforts. Chemical and radioactive wastes are byproducts of nuclear material production processes.

The Federal Facility Agreement (FFA) lists the Burma Road Rubble Pit (BRRP) source unit (23 1-4F; Figure 2) as a Resource Conservation and Recovery Act (RCRA)/ Comprehensive Environmental Response, Compensation, and Liability Act (CERCLA) unit that required further evaluation. An investigation/assessment process that integrates and combines the RCRA Facility Investigation (RFI) process with the CERCLA Remedial Investigation (RI) to determine the actual or potential impact to human health and the environment was performed.

The BRRP, 231-4F, is located approximately one-half mile southwest of FArea Separations Facility and one-tenth mile southwest of C Road. The BRRP is between Upper Three Runs Creek (approximately 4000 feet to the northwest) and Four Mile Creek (approximately one mile to the southwest). A westward trending tributary to the Upper Three Runs Creek is located approximately 2,000 feet to the north. The BRRP ground surface elevation is approximately 290 feet mean sea level. Surface runoff is northwestward toward the tributary. The soil type that exists at the BRRP consists of Udorthents.

The BRRP consists of two unlined earthen pits dug into surficial soil and filled with various waste materials. The BRRP was originally reported to be 485 feet long, 125 to 150 feet wide, and at least 10 feet deep. A GPR survey, conducted in September 1988 , indicates that the BRRP area consists of two generally rectangular pits (GPR Zone 1 and GPR Zone 2, Figure 3), each about 400 feet long, up to 50 feet wide, and 10 feet deep. A small circular area (GPR Zone 3, Figure 3) of disturbed soil was detected adjacent to these pits and is considered to have been used as a source of backfill for the pits.

\section{Ix. Operable Unit History and Compliance History}

\section{Operable Unit History}

The BRRP was used from 1973 to 1983 for the disposal of dry inert rubble such as wood, trash, wire, bottles, plastic, rubble, foam, concrete, etc. No record of hazardous substance disposal at the BRRP has been found. In 1983, disposal at the BRRP ceased and it was backfilled with soil. The area is currently delineated by orange marker balls at the perimeter of the waste unit.

\section{Compliance History}

At SRS, waste materials are managed which are regulated under the RCRA. Certain SRS activities have required Federal operating or post-closure permits under RCRA. SRS received a RCRA hazardous waste permit from the South Carolina Department of Health and Environmental Control (SCDHEC) on September 30, 1987. Part V of the permit mandates that SRS establish and implement an RFI Program to fulfill the requirements specified in Section 3004(u) of the Federal permit. 


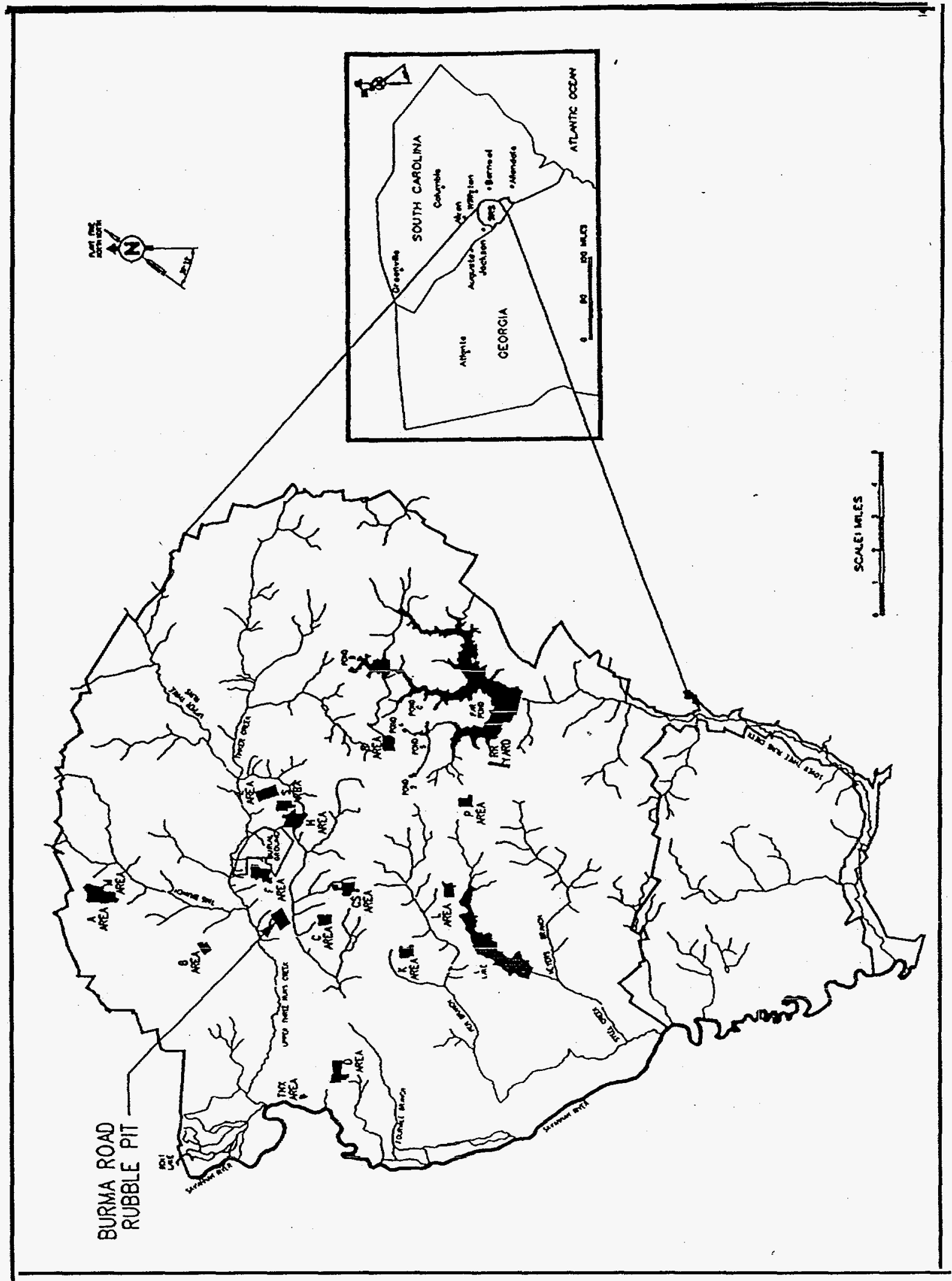

Figure 1. Location of the Burma Road Rubble Pit at the Savannah River Site. 
Record of Decision for the Burma Road Rubble Pit (231-4F)

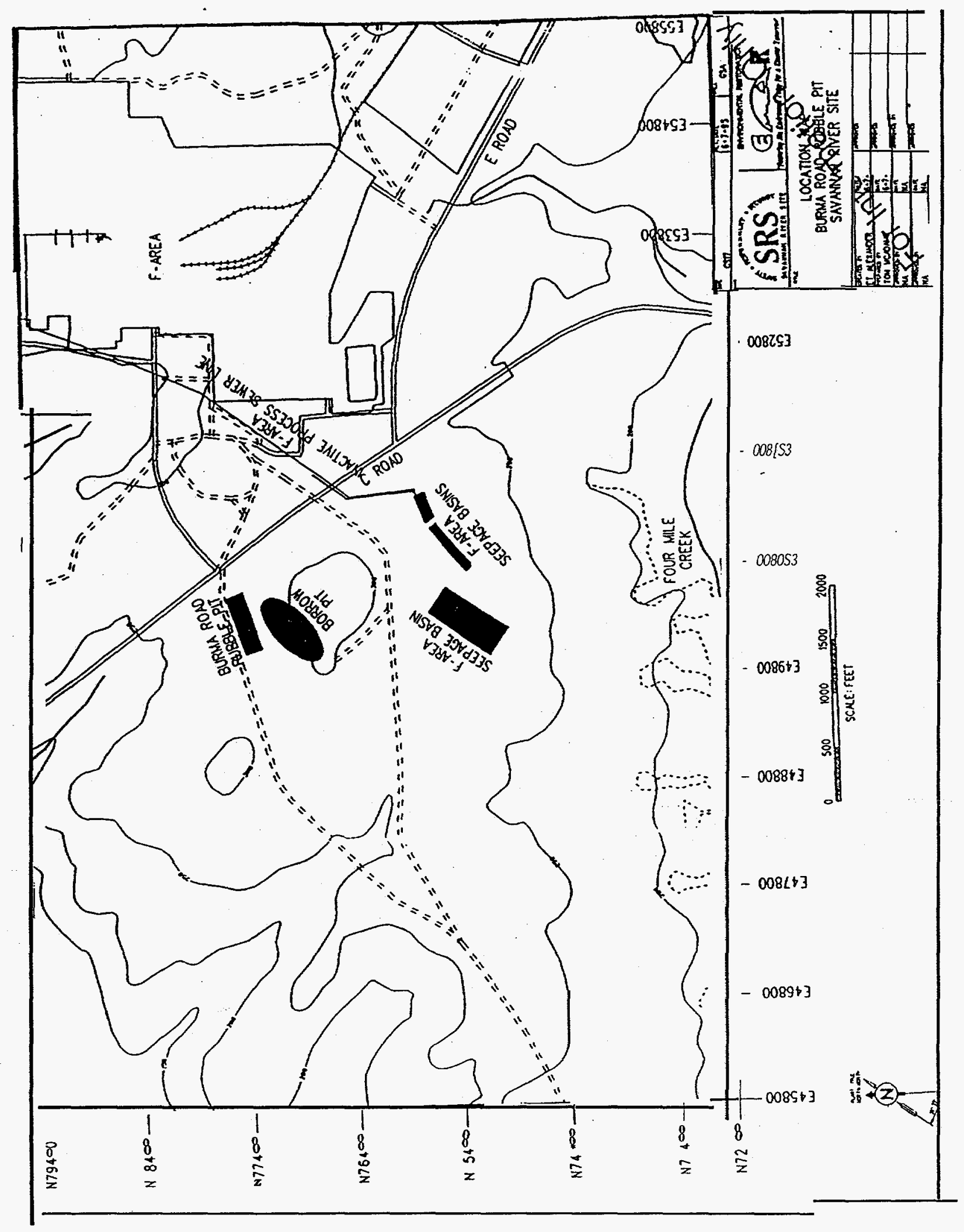

Figure 2. Location of the Burma Road Rubble Pit Waste Unit: 

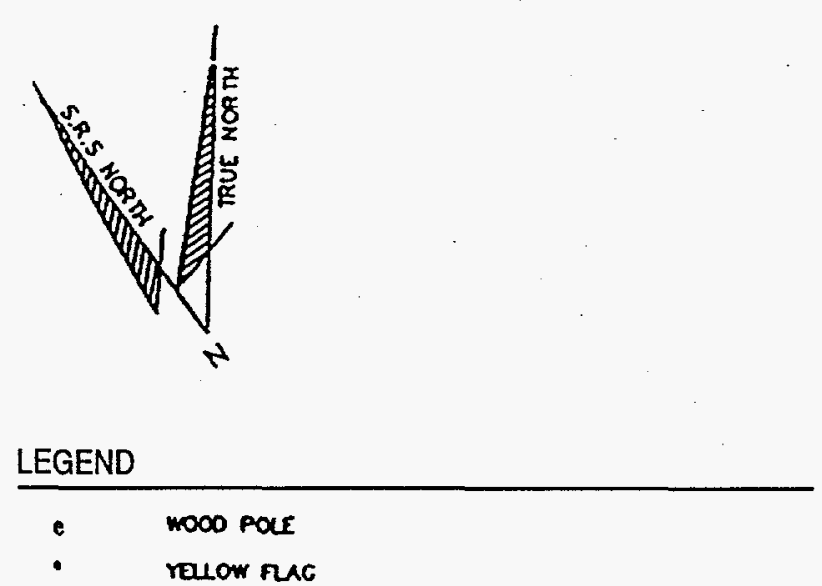

DIIJ AREA Of OISTURBED SOI

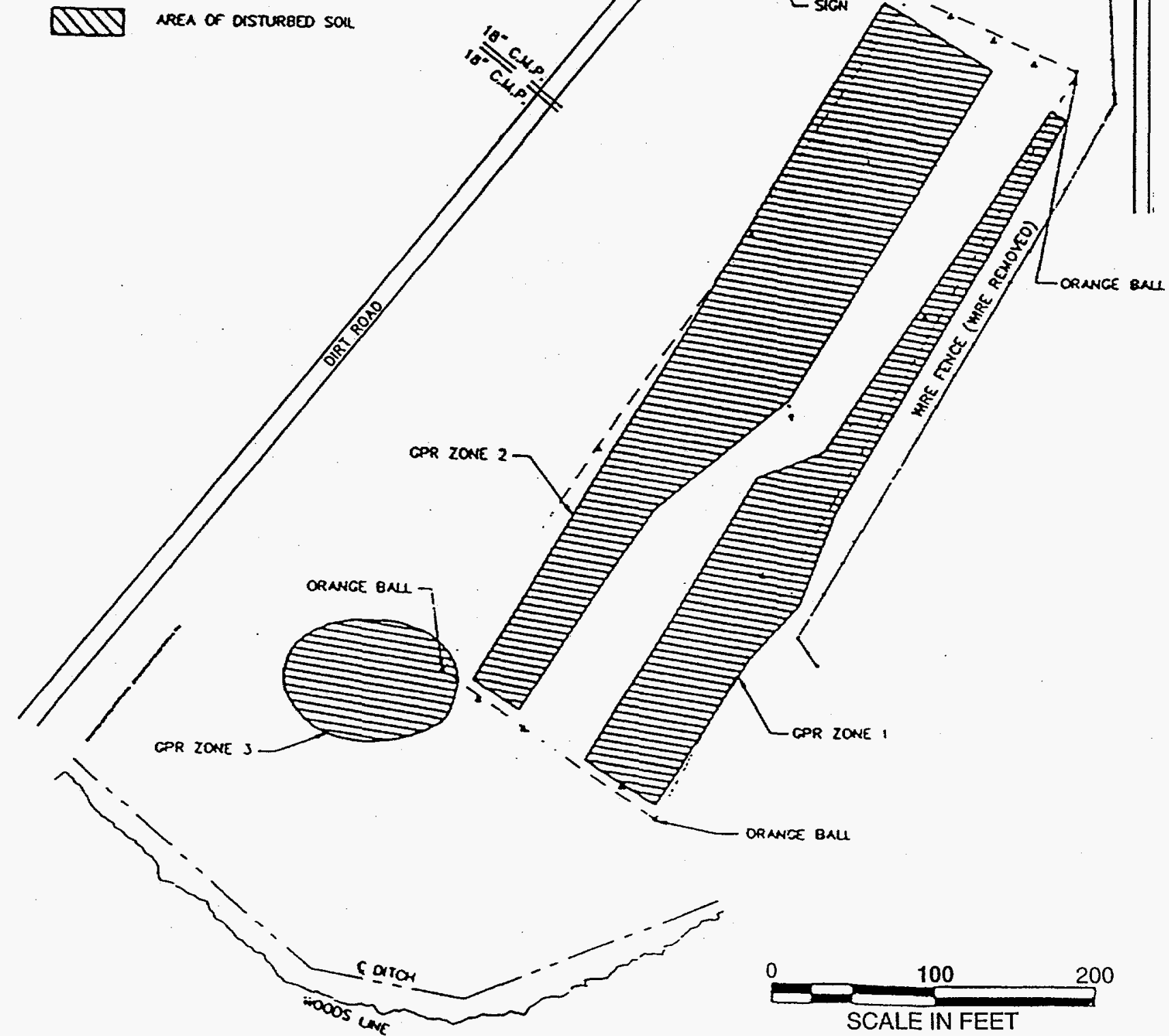

Figure 3. General Configuration of the Burma Road Rubble Pit. 
Hazardous substances, as defined by CERCLA, are also present in the environment at SRS. On December 21, 1989 , the SRS was placed on the National Priorities List (NPL). A site placed on the NPL comes under the jurisdiction of CERCLA. In accordance with Section 120 of CERCLA, DOE has negotiated an FFA (FFA, 1993) with the U.S. Environmental Protection Agency (EPA) and SCDHEC to coordinate remedial activities at SRS into one comprehensive strategy which fulfills these dual regulatory requirements.

The BRRP RFI/RI investigation was conducted from November 1993 to February 1994. The results of the RFI/RI indicate that the BRRP source unit soils pose minimal risk to human health or the environment. The only soil contamination found at the BRRP source unit was arsenic at a concentration of $1.74 \mathrm{mg} / \mathrm{kg}$. This soil concentration led to a risk value of $1.9 \mathrm{x}$ 10-6 for the future residential adult (i.e., there is a 1.9 in one million chance of developing cancer from the ingestion of arsenic) and a risk value of $2.8 \times 10-6$ for the future residential child (i.e., there is a 2.8 in one million chance of developing cancer from the ingestion of arsenic). Based on these risk values, no action is warranted at the BRRP source unit soils. No other alternatives were considered. This is a proposed final CERCLA action for the BRRP source unit soils only.

Since the arsenic concentration does not appear to be from the BRRP Operable Unit, the source of the arsenic will be evaluated on a site-wide scale during the implementation of the Soil Background Study (or potentially the Site-wide Soil Integrator Operable Unit Workplan).

Groundwater contamination found beneath the BRRP is due to migration from upgradient sources such as the F-Area Inactive Process Sewer Lines and thus will not be addressed in this remedial action. Following an investigation on upgradient groundwater contaminant sources, a determination will be made as to what corrective action might be appropriate for the groundwater beneath the BRRP.

Public participation requirements are listed in Sections 113 and 117 of CERCLA. These requirements include establishment of an Administrative Record File that documents the selection of remedial alternatives and allows for review and comment by the public regarding those alternatives. The Administrative Record File must be established "at or near the facility at issue." The SRS Public Involvement Plan (PIP) (DOE, 1994) is designed to facilitate public involvement in the decision-making process for permitting, closure, and the selection of remedial alternatives.

A Proposed Plan (PP) was submitted that fulfills the requirements of CERCLA Section 117 (a) by providing the public an opportunity to participate in the selection of a remedial action. The PP presented the preferred alternative and the rationale for selecting the alternative. DOE, in consultation with EPA and SCDHEC selected the final action for the BRRP source unit soils following the public comment period.

\section{m. Highlights of Community Participation}

Public participation requirements are listed in Sections 113 and 117 of CERCLA. These requirements include the establishment of an Administrative Record File that documents the investigation and selection of the remedy for addressing the BRRP. The SRS PIP (DOE, 1994) is designed to facilitate public involvement in the decision-making processes for permitting, closure, and the selection of remedial alternatives. The SRS PIP addresses the requirements of RCRA, CERCLA, and the National Environmental Policy Act (NEPA). Section 117(a) of CERCLA, as amended, requires the preparation of a proposed plan as part of the site remedial process. The Proposed Plan for the Burma Road Rubble Pit (2314F) (WSRC, 1995 b), which is part of the Administrative Record File, highlights key 
aspects of the investigation and identifies the preferred action for addressing the BRRP soils only.

The Administrative Record File, which contains the information pertaining to the selection of the response action, was made available at the EPA office and at the following locations:

U.S. Department of Energy

Public Reading Room

Gregg-Graniteville Library

University of South Carolina-Aiken

171 University Parkway

Aiken, South Carolina 29801

(803) 641-3465

Thomas Cooper Library

Government Documents Library

University of South Carolina

Columbia, South Carolina 29208

(803) 777-4866

Similar information is available through the repositories listed below:

Reese Library

Augusta College

2500 Walton Way

Augusta, Georgia 30910

(706) $737-1744$

Asa H. Gordon Library

Savannah State College

Tompkins Road

Savannah, Georgia 31404

(912) $356-2183$

The public was notified of the comment period for the proposed plan through mai lings of the SRS Environmental Bulletin, a newsletter sent to approximately 1400 citizens in South Carolina and Georgia, and through notices in local newspapers including the Aiken Standard, the Augusta Chronicle, the Allendale Citizen Leader, and the Barnwell People-Sentinel.

The public comment period for the Proposed Plan began on January 10, 1996 and ended on February 8, 1996. Comments received are addressed in the Responsiveness Summary (Appendix A).

\section{Iv. Scope and Role of Operable Unit Within the Site Strategy}

The overall strategy for addressing the BRRP source unit was to: (1) characterize the waste unit delineating the nature and extent of contamination and identifying the media of concern (perform the RFI/RI); (2) perform a baseline risk assessment to evaluate media of concern, chemicals of concern, exposure pathways, and characterize potential risks; and (3) evaluate and perform a final action to remediate, as needed, the identified media(s) of concern.

The investigation and risk assessment have been completed for the BRRP source unit. Since the results of the investigation indicate that the BRRP source unit soils pose minimal risk to human health or the environment, no action was recommended by the Proposed Plan for the Burma Road Rubble Pit (23I-4F) (WSRC, 1995 b). Only non-hazardous, inert material (e.g., wood, trash, wire, bottles, plastic, rubble, foam, concrete, etc.) was placed at the BRRP source unit. A notification, identifying the presence of buried, inert debris, will be placed in the Aiken County Records which will include a survey plat, prepared and certified by a professional land surveyor, of the area .

Although there is groundwater contamination beneath the BRRP, the groundwater contamination is due to migration from upgradient sources such as the F-Area Inactive Process Sewer Lines (Figure 2) and thus will not be addressed by this remedial action. The depth to the water table beneath the BRRP is 61 to 83 feet.

Figure 4 illustrates the regional groundwater flow direction in the vicinity of the BRRP. The map indicates west-northwestward flow of the shallow aquifer system groundwater in the BRRP area. Groundwater data from two nearby areas, the F-Area Seepage Basins and the F-Area Separations Facility which 

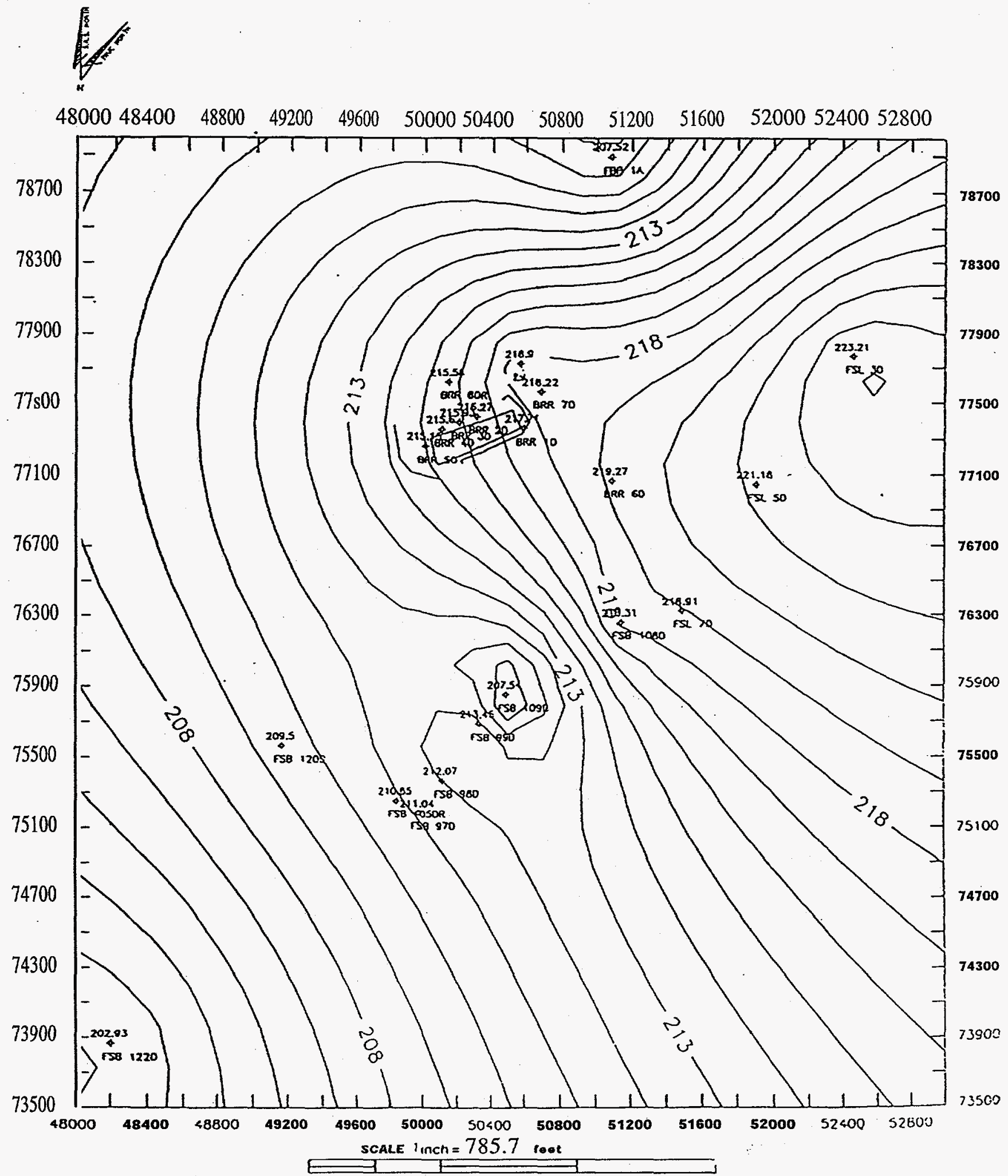

Figure 4. Burma Road Rubble Pit Regional Groundwater Flow Map (Second Quarter 1994). 
includes the Inactive Process Sewer Lines, suggest that these areas may have impacted the BRRP. The F-Area Separations Facility is located approximately 2,000 feet northeast of the BRRP. The F-Area Seepage Basins are located approximately 1,100 feet to the southeast of the BRRP.

Following an investigation on upgradient groundwater contaminant sources, a determination will be made as to what corrective action might be appropriate.

The BRRP is a source control operable unit (OU) located within the Upper Three Runs Watershed. Several source control and groundwater OUS, including the $\mathrm{F}$ - and $\mathrm{H}$ Area Groundwater OU, within this watershed will be evaluated to determine impacts, if any, to associated streams and wetlands. It has been determined that the BRRP source control OU does not contribute contamination to the area groundwater or surrounding soils. The proposed action for the BRRP source unit soils is a final action.

\section{Summary of Operable Unit Characteristics}

The BRRP was used from 1973 to 1983 for the disposal of dry inert rubble such as metal, concrete, lumber, poles, light fixtures, and glass. No record of hazardous substances disposal at the BRRP has been found. In 1983, disposal at the BRRP ceased and it was backfilled with soil. The area is currently delineated by orange marker balls at the perimeter of the waste unit.

\section{RFURI Characterization}

The BRRP RFI/RI investigation was conducted from November 1993 to February 1994. Samples were collected to characterize the chemical concentrations in soil, groundwater, sediments, and surface water at the BRRP.

Sampling and investigation activities are summarized below. Detailed information regarding sampling/investigation activities can be found in the Final RFI/RI Report for
Burma Road Rubble Pit (231 -4F), (WSRC, 1995a).

Surface and subsurface soil samples were collected from seventeen locations within the BRRP in areas of suspected contamination (e.g., the soil borings were located in areas where a soil gas anomaly was detected or adjacent to potential underground objects and/or areas of high metal concentrations as indicated by anomalies in the GPR, electromagnetic (EM), or magnetometer surveys). These sampling depths provide a representation of soil conditions above the fill material and at the bottom layer below the fill material.

During the sampling, none of the soil borings encountered any containers (e.g., drums), liquid, sludge, or experienced a roddrop that would indicate a drum or container had been punctured. Only inert materials (e.g., wood, trash, wire, bottles, plastic, rubble, foam, concrete, etc.) were encountered during the soil sampling.

Four background subsurface soil samples and two background surface soil samples were collected to gather data for statistical and comparative analysis against samples collected in the areas suspected of containing hazardous material. The background soil samples were located in areas that were away from GPR Zones 1,2, 3 (Figure 3) and were outside of the soil gas anomalies. The background surface soil samples were located upgradient and at a sufficient distance from the BRRP source unit so as to preclude any impact from the unit.

Background surface water samples were unavailable because there is no upgradient body of surface water within a reasonable distance of the waste unit from which to obtain unit-specific background samples.

All samples were analyzed in accordance with EPA-approved protocols. The detailed analytical results are contained in the Quality Control Summary Report for the Burma Road Rubble Pit RFI/RI Unit 
Assessment (WSRC, 1994). Validation and verification of the analytical data were performed as part of the RFI/RI data review process; therefore, the data were considered acceptable for this evaluation.

Nine new groundwater monitoring wells were installed at varying depths in 3 three-well clusters. Of the 14 wells that exist at BRRP (new and existing), six wells are considered to be upgradient wells. However, the entire BRRP is downgradient of the SRS F-Area Separations Facility and the entire BRRP well network may be impacted by groundwater migration from F-Area.

The BRRP RFI/RI investigation process concluded that source characterization has shown that historical documents are correct in stating that only inert material was disposed of at the BRRP; therefore, the BRRP is not expected to be a future source of contamination.

\section{Summary of Operable Unit Risks}

The BRRP operable unit investigation addressed the rubble (potential source term), surrounding soils, and the groundwater under the facility. This section summarizes the baseline risk assessment information associated with the BRRP operable unit. It should be noted, however, that the remedial action proposed by this plan is for the BRRP soils only. The groundwater contamination will be addressed following an investigation on upgradient contaminant sources.

\section{Human Health Risk Assessment}

As part of the investigation/assessment process for the BRRP source unit, a risk assessment was performed using the data generated during the assessment phase. Detailed information regarding the development of contaminants of potential concern, the fate and transport of contaminants, and the risk assessment can be found in the Final RFI/RI Report for Burma Road Rubble Pit (23I -4F). (WSRC, 1995a).
The process of designating the constituents of potential concern (COPCs) was based on consideration of background concentrations, frequency of detection, the relative toxic potential of the chemicals, and chemical nutrient status. COPCs are the constituents that are potentially site-related and whose data are of sufficient quality for use in the risk assessment. COPCs included volatile organic compounds, semi-volatile organic compounds, metals and other inorganic analytes, and radionuclides identified through approved site characterization activities.

An exposure assessment was performed to provide an indication of the potential exposures which could occur based on the chemical concentrations detected during sampling activities. The only existing (current) exposure scenario identified for the BRRP was for environmental researchers who may work or traverse the BRRP on an intermittent/limited basis. Future exposure scenarios identified for the BRRP included future environmental researchers as well as conservative future residential adult and child and an occupational worker.

Per EPA guidance, the carcinogenic (cancer) risks and non-carcinogenic hazards should be calculated to determine the appropriate remedial action for a waste unit.

Cancer risks are estimated as the incremental probability of an individual developing cancer over a lifetime as a result of pathway-specific exposure to carcinogenic contaminants. The risk to an individual resulting from exposure to nonradioactive chemical carcinogens is expressed as the increased probability of cancer occurring over the course of a 70 year lifetime. Cancer risks are related to the EPA target range of one in ten thousand $(1.0 \times 10-4)$ to one in one million $\left(1.0 \times 10^{-6}\right)$ for incremental cancer risk at NPL sites. This means that one in ten thousand to one in one million people may develop cancer over a lifetime as a result of exposure to cancer-causing contaminants. Risk levels at or above $1.0 \times 10^{-4}$ are considered 
significant. In order to account for simultaneous exposure to multiple carcinogens through a given pathway, the risk calculated for each individual carcinogen in that medium were summed to obtain an estimate of the total cancer risk for the pathway.

Non-carcinogenic effects are evaluated by comparing an exposure level over a specified time period (e.g., lifetime) with a reference dose (RfD) derived for a similar exposure period. To evaluate the non-carcinogenic effects of exposure to soil contaminants, the hazard quotient (HQ), which is the ratio of the exposure dose to the RfD, is calculated for each contaminant. The noncarcinogenic HQ assumes that below a given level of exposure (e.g., the RfD), even sensitive populations are unlikely to experience adverse health effects. If the exposure level exceeds the threshold there may be concern for potential noncarcinogenic health effects.

HQs are summed for each exposure pathway to create a pathway specific hazard index (HI) for each exposure scenario. The more the HI exceeds unity $(1.0)$, the greater the concern that adverse health effects will occur.

The reasonable maximum exposure concentration value was used as the exposure point concentration.

In order to determine the carcinogenic (cancer) and non-carcinogenic hazards the following general exposure assumptions were used inthebaseline risk assessment:

\section{Current Land Use Scenario}

Environmental Researcher

The adult environmental researcher receptor was assumed to enter onto the BRRP unit on an intermittent basis. The adult was assumed to work in the BRRP area for 72 days per year (approximately one quarter of the year). Exposures were evaluated for a shortterm and long-term scenario (over a halfyear and a 25 year interval, respectively). It was also assumed that the person would remain at the BRRP unit or in the BRRP vicinity for a four hour work period. The person would wear clothing which covers all bodily areas with the exception of the face, hands, and forearms.

\section{Future Land Use Scenarios Residential Scenario}

The future residential adult receptor was assumed to reside on the BRRP for a longterm duration of 30 years and/or a shortterm duration of 5 years. It was anticipated that the adult residential person would engage in gardening/yard maintenance activities for a total of eight hours per week year-round (four two-hour periods per week, 350 days/year, assuming approximately two weeks spent away from the residence per year). During such activities, the person would wear clothing which covers all bodily areas with the exception of the face, arms, hands, and lower legs.

The future residential child receptor was assumed to reside on the BRRP between the ages of two through seven years. The child was assumed to live in a house constructed in close proximity to the BRRP. The child would engage in outdoor activities 350 days/year (assuming approximately two weeks spent away from the residence per year). The average rate for time spent outdoors would encompass periods when exposures may be more or less frequent, as well as times when adverse weather would prohibit outdoor activity. It was assumed that the young child would remain outdoors for a four hour period.

\section{Occupational Worker}

The primary receptor examined under the future commercial use scenario was an onsite adult worker aged 18 years or older. Soil exposure could occur during normal day-today activities for an on-site worker.

\section{Environmental Researcher}

The adult environmental researcher receptor was assumed to enter onto the BRRP unit on an intermittent basis. The adult was assumed to work in the BRRP area for 72 days per year (approximately one quarter of the year). Exposures were evaluated for a shortterm and long-term scenario (over a halfyear and a 25 year interval, respectively). It 
was also assumed that the person would remain at the BRRP unit or in the BRRP vicinity for a four hour work period. The person would wear clothing which covers all bodily areas with the exception of the face, hands, and forearms.

\section{Current Land Use - Noncarcinogenic Hazard Indices}

Table 1 provides a summary of the noncarcinogenic hazard indices and applicable constituents of concern (COCs) associated with the current land use scenario for the BRRP unit soils.

The total noncarcinogenic (noncancer) hazard index did not exceed unity for the environmental researcher receptor evaluated in the current land use scenario. This indicates that potential adverse health effects are not likely to occur for the current environmental researcher.

\section{Current Land Use - Carcinogenic Risks}

Table 2 provides a summary of the carcinogenic risks and applicable COCS associated with the current land use scenario for the BRRP unit soils.

Under the current land use scenario, the total carcinogenic (cancer) risk (for chemicals and radionuclides) did not exceed a level of $1.0 \times 10^{-6}$ for the environmental researcher which indicates that carcinogenic risk from the unit soils is not significant.

\section{Future Land Use - Noncarcinogenic Hazard Indices}

Table 3 provides a summary of the noncarcinogenic hazard indices and applicable COCS associated with the future land use scenario for the BRRP unit soils.

The HIs were all less than one, indicating that adverse noncarcinogenic effects are unlikely for the following pathways:

- incidental ingestion of soil,
- dermal contact with soil (based on exposure to the face, arms, hands, and lower legs),

- inhalation of chemicals in ambient air, and

- ingestion of homegrown produce.

\section{Future Land Use - Carcinogenic Risks}

For the future residential adult, the only estimated risk from the unit soils was the ingestion of arsenic with a risk value of 1.9 $x 10^{-6}$ (i.e., there is a 1.9 in one million chance of developing cancer from the ingestion of arsenic). And, for the future residential child, the only estimated risk from the unit soils was the ingestion of arsenic with a risk value of $2.8 \times 10^{-6}$ (i.e., there is a 2.8 in one million chance of developing cancer from the ingestion of arsenic). The arsenic level associated with both risks was $1.74 \mathrm{mg} / \mathrm{kg}$.

Table 4 provides a summary of the carcinogenic risks and applicable COCS associated with the future land use scenario for the BRRP unit soils.

\section{Ecological Risk Assessment}

An ecological risk assessment was conducted to assess the potential impacts to biota caused by exposure to chemicals and radionuclides at the $B R R P$.

A site ecological reconnaissance was conducted in August 1994. No wetlands or threatened and endangered (T\&E) species were observed in the vicinity of the BRRP, and use of the site by T\&E species was not expected. The potential media of contaminant exposure were surface soil, sediment, and surface water at or near the BRRP.

Based on the ecological risk assessment, ecological impacts from the BRRP source unit are unlikely. 
Table 1- Current Land Use - Noncarcinogenic Hazard Index

\begin{tabular}{||l|l|l|l|l|l||}
\hline RECEPTOR & \multicolumn{4}{|c|}{ EXPOSURE TO CHEMICALS (HAZARD INDEX) } \\
\hline & $\begin{array}{l}\text { Soil - } \\
\text { Ingestion }\end{array}$ & $\begin{array}{l}\text { Soil - } \\
\text { Dermal }\end{array}$ & $\begin{array}{l}\text { Soil - } \\
\text { Inhalation }\end{array}$ & $\begin{array}{l}\text { Total (Soils } \\
\text { Only) }\end{array}$ & Cots \\
\hline $\begin{array}{l}\text { Environmental } \\
\text { Researcher - ST \& LT }\end{array}$ & 0.041 & 0.024 & 0.0000034 & 0.065 & NA \\
\hline
\end{tabular}

Table 2- Current Land Use - Carcinogenic Risks

\begin{tabular}{|l|l|l|l|l|l||}
\hline RECEPTOR & \multicolumn{5}{|c||}{ EXPOSURE TO CHEMCALS } \\
\hline & $\begin{array}{l}\text { Soil - } \\
\text { Ingestion }\end{array}$ & $\begin{array}{l}\text { Soil - } \\
\text { Dermal }\end{array}$ & $\begin{array}{l}\text { Soil - } \\
\text { Inhalation }\end{array}$ & $\begin{array}{l}\text { Total (Soils } \\
\text { Only) }\end{array}$ & Cots \\
\hline $\begin{array}{l}\text { Environmental } \\
\text { Researchen - ST }\end{array}$ & $3.2 \times 10-9$ & $3.4 \times 10^{-10}$ & $2.6 \times 10^{-11}$ & $3.6 \times 10^{-9}$ & $\mathrm{NA}$ \\
\hline $\begin{array}{l}\text { Environmental } \\
\text { Researcher - LT }\end{array}$ & $1.6 \times 10^{-7}$ & $1.7 \times 10^{-8}$ & $1.3 \times 10^{-9}$ & $1.8 \times 10^{-7}$ & $\mathrm{NA}$ \\
\hline RECEPTOR & \multicolumn{5}{|c|}{ EXPOSURE TO RADIONUCLIDES } \\
\hline & $\begin{array}{l}\text { Soil - } \\
\text { Ingestion }\end{array}$ & $\begin{array}{l}\text { Soil - } \\
\text { External }\end{array}$ & $\begin{array}{l}\text { Soil - } \\
\text { Inhalation }\end{array}$ & $\begin{array}{l}\text { Total (Soils } \\
\text { Only) }\end{array}$ & Cots \\
\hline $\begin{array}{l}\text { Environmental } \\
\text { Researcher - ST }\end{array}$ & $5.3 \times 10^{-12}$ & $1.9 \times 10^{-8}$ & $1.6 \times 10^{-15}$ & $1.9 \times 10^{-8}$ & $\mathrm{NA}$ \\
\hline $\begin{array}{l}\text { Environmental } \\
\text { Researcher - LT }\end{array}$ & $1.5 \times 10^{-10}$ & $7.1 \times 10^{-8}$ & $1.2 \times 10^{-14}$ & $7.1 \times 10^{-8}$ & $\mathrm{NA}$ \\
\hline \hline
\end{tabular}

Table 3- Future Land Use - Noncarcinogenic Hazard Index

\begin{tabular}{||l|l|l|l|l|l|l||}
\hline RECEPTOR & \multicolumn{5}{|c||}{ EXPOSURE TO CHEMICALS (HAZARD INDEX) } \\
\hline & $\begin{array}{l}\text { Soil - } \\
\text { Ingestion }\end{array}$ & $\begin{array}{l}\text { Soil - } \\
\text { Dermal }\end{array}$ & $\begin{array}{l}\text { Soil - } \\
\text { Inhalation }\end{array}$ & $\begin{array}{l}\text { Produce - } \\
\text { Ingestion }\end{array}$ & $\begin{array}{l}\text { Total (Soils } \\
\text { Only) }\end{array}$ & Cot S \\
\hline $\begin{array}{l}\text { Environmental } \\
\text { Researcher - ST \& } \\
\text { LT }\end{array}$ & 0.041 & 0.024 & 0.0000034 & NA & 0.065 & NA \\
$\begin{array}{l}\text { Residential } \\
\text { Adult - ST \& LT }\end{array}$ & 0.026 & 0.029 & 0.0000027 & 0.00013 & 0.055 & NA \\
$\begin{array}{l}\text { Residential } \\
\text { Child - ST }\end{array}$ & 0.23 & 0.11 & 0.000013 & 0.00030 & 0.34 & NA \\
\hline $\begin{array}{l}\text { Occupational } \\
\text { Worker - ST \& LT }\end{array}$ & 0.14 & 0.083 & 0.000024 & NA & 0.22 & NA \\
\hline \hline
\end{tabular}

COCs - Constituents of Concern LT - Long Term
ST - Short Term

NA - Not Applicable 
Table 4- Future Land Use Carcinogen ic Risks

\begin{tabular}{|c|c|c|c|c|c|c|}
\hline RECEPTOR & \multicolumn{6}{|c|}{ E:XPOSURE TO CHEMICALS } \\
\hline & $\begin{array}{l}\text { Soil - } \\
\text { Ingestion }\end{array}$ & $\begin{array}{l}\text { Soil - } \\
\text { Dermal }\end{array}$ & \begin{tabular}{|l|} 
Soil - \\
Inhalation
\end{tabular} & $\begin{array}{l}\text { Produce - } \\
\text { Ingestion }\end{array}$ & $\begin{array}{l}\text { Total (Soils } \\
\text { Only) }\end{array}$ & Cots \\
\hline $\begin{array}{l}\text { Environmental } \\
\text { Researcher - ST }\end{array}$ & $3.2 \times 10^{-9}$ & $3.4 \times 10^{-10}$ & $2.6 \times 10^{-11}$ & $\mathrm{NA}$ & $3.6 \times 10^{-9}$ & $\mathrm{NA}$ \\
\hline $\begin{array}{l}\text { Environmental } \\
\text { Researcher - LT }\end{array}$ & $1.6 \times 10^{-7}$ & $1.7 \times 10^{-8}$ & $1.3 \times 10^{-9}$ & $\mathrm{NA}$ & $1.8 \times 10^{-7}$ & $\mathrm{NA}$ \\
\hline $\begin{array}{l}\text { Residential } \\
\text { Adult - ST }\end{array}$ & $3.1 \times 10^{-7}$ & $1.6 \times 10^{-8}$ & $7.5 \times 10^{-9}$ & $2.0 \times 10^{-8}$ & $3.5 \times 10^{-7}$ & $\mathrm{NA}$ \\
\hline $\begin{array}{l}\text { Residential } \\
\text { Adult - LT } \\
\end{array}$ & $10 \% 110$ & $9.8 \times 10^{-8}$ & $4.5 \times 10^{-8}$ & $1.2 \times 10^{-7}$ & $2,2,16$ & Arsenic \\
\hline $\begin{array}{l}\text { Residential } \\
\text { Child - ST }\end{array}$ & $28 \% 1106$ & $6.4 \times 10^{-8}$ & $3.6 \times 10^{-8}$ & $4.4 \times 10^{-8}$ & 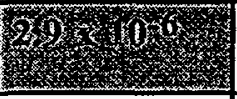 & Arsenic \\
\hline $\begin{array}{l}\text { Occupational } \\
\text { Worker - ST }\end{array}$ & $1.1 \times 10^{-7}$ & $1.2 \times 10^{-8}$ & $1.8 \times 10^{-9}$ & $\mathrm{NA}$ & $1.2 \times 10^{-7}$ & NA \\
\hline $\begin{array}{l}\text { Occupational } \\
\text { Worker - LT }\end{array}$ & $5.6 \times 10^{-7}$ & $5.8 \times 10^{-8}$ & $9.0 \times 10^{-9}$ & NA & $6.3 \times 10^{-7}$ & NA \\
\hline \multirow[t]{2}{*}{ RECEPTOR } & \multicolumn{6}{|c|}{ EXPOSURE TO RADIONUCLIDES } \\
\hline & \begin{tabular}{|l|} 
Soil - \\
Ingestion
\end{tabular} & $\begin{array}{l}\text { Soil - } \\
\text { External } \\
\end{array}$ & \begin{tabular}{|l|} 
Soil - \\
Inhalation \\
\end{tabular} & $\begin{array}{l}\text { Produce - } \\
\text { Ingestion }\end{array}$ & $\begin{array}{l}\text { Total (Soils } \\
\text { Only) }\end{array}$ & Cots \\
\hline $\begin{array}{l}\text { Environmental } \\
\text { Researcher - ST }\end{array}$ & $5.3 \times 10^{-12}$ & $1.9 \times 10^{-8}$ & $1.6 \times 10^{-15}$ & NA & $1.9 \times 10^{-8}$ & $\mathrm{NA}$ \\
\hline $\begin{array}{l}\text { Environmental } \\
\text { Researcher - LT }\end{array}$ & $1.5 \times 10^{-10}$ & $7.1 \times 10^{-8}$ & $1.2 \times 10^{-14}$ & $\mathrm{NA}$ & $7.1 \times 10^{-8}$ & $\mathrm{NA}$ \\
\hline $\begin{array}{l}\text { Residential } \\
\text { Adult - ST }\end{array}$ & $4.0 \times 10^{-10}$ & $2.6 \times 10^{-9}$ & $2.1 \times 10^{-13}$ & $2.8 \times 10^{-14}$ & $2.6 \times 10^{-7}$ & NA \\
\hline $\begin{array}{l}\text { Residential } \\
\text { Adult - LT }\end{array}$ & $1.6 \times 10^{-9}$ & $3.6 \times 10^{-7}$ & $3.7 \times 10^{-13}$ & $1.1 \times 10^{-13}$ & $3.6 \times 10^{-7}$ & $\mathrm{NA}$ \\
\hline $\begin{array}{l}\text { Residential } \\
\text { Child - ST }\end{array}$ & $8.3 \times 10^{-10}$ & $2.6 \times 10^{-7}$ & $2.4 \times 10^{-13}$ & $1.5 \times 10^{-14}$ & $2.6 \times 10-7$ & $\mathrm{NA}$ \\
\hline $\begin{array}{l}\text { Occupational } \\
\text { Worker - ST }\end{array}$ & $\overline{1.4 \times 10^{-10}}$ & $7.8 \times 10^{-8}$ & $5.0 \times 10^{-14}$ & $\mathrm{NA}$ & $7.8 \times 10^{-8}$ & NA \\
\hline $\begin{array}{l}\text { Occupational } \\
\text { Worker - LT }\end{array}$ & $9.0 \times 10^{-10}$ & $1.1 \times 10^{-7}$ & $8.5 \times 10^{-14}$ & $\mathrm{NA}$ & $1.1 \times 10^{-7}$ & $\mathrm{NA}$ \\
\hline
\end{tabular}

Shaded items represent exceedances.

ST - Short Term
LT - Long Term

COCs - Constituents of Concern

NA - Not Applicable 


\section{Description of the No Action Alternative}

According to the EPA guidance document Guidance on Preparing Superfund Decision Documents (EPA, 1989), if there is no current or potential threat to human health or the environment and no action is warranted, the CERCLA 121 requirements are not triggered. This means that there is no need to evaluate other alternatives or the no action alternative against the nine criteria specified under CERCLA.

Under the No Action alternative, no treatment will be performed, no new institutional controls or engineering controls will be implemented, and no cost is associated with implementing the alternative. According to CERLCA regulations, Section 121, if no action is the preferred action, then no applicable or relevant and appropriate requirements are associated with the alternative.

Since the BRRP source unit poses minimal known risk to human health or the environment and the no action alternative is warranted, it does satisfy the CERCLA criteria. The no action alternative is intended to be the final action for the BRRP source unit soils only. This solution is meant to be permanent and effective in both the long and short term. The no action decision is the least cost option with no capital, operating, or monitoring costs, and is protective of human health and the environment.

The groundwater contamination beneath the BRRP is due to migration from upgradient sources such as the F-Area Inactive Process Sewer Lines and thus will not be addressed by this remedial alternative. Following an investigation on upgradient groundwater contaminant sources, a determination will be made as to what corrective action might be appropriate for the groundwater beneath the BRRP.

\section{Explanation of Significant Changes}

No significant changes were made to the Record of Decision based on the public comment period for the proposed plan. Two public comments were received. However, they did not have an impact on the no action preferred alternative decision. One of the comments required clarification information to be added to Section VI, Summary of Operable Unit Risks (see Appendix A). 


\section{References}

DOE (U.S. Department of Energy), 1994. Public Involvement, A Plan for the Savannah River Site. Savannah River Operations Office, Aiken, South Carolina.

EPA (U.S. Environmental Protection Agency), 1989. Guidance on Preparing Superfund Decision Documents. Office of Solid Waste and Emergency Response OSWER Directive 9355.3-02.

EPA (U.S. Environmental Protection Agency), 1991. Guide to Develop Superfund No Action, Interim Action, and Contingency RODS. Office of Solid Waste and Emergency Response OSWER Directive 9355 .3-02FS-3.

FFA, 1993. Federal Facility Agreement for the Savannah River Site, Administrative Docket No. 89-05-FF, (Effective Date: August 16, 1993).

WSRC (Westinghouse Savannah River Company), 1993. Phase II RFI/RI Work Plan for the Burma Road Rubble Pit $(231$-4F) (U), WSRC-RP-90- 1104, Rev. 2, Westinghouse Savannah River Company, Aiken, South Carolina.

WSRC (Westinghouse Savannah River Company), 1994. Quality Control Summary Report for the Burma Road Rubble Pit RFI/RI Unit Assessment (U), ES H-EMS-94-0425, Westinghouse Savannah River Company, Aiken, South Carolina.

WSRC (Westinghouse Savannah River Company), 1995a. Final RFI/RI Report for Burma Road Rubble Pit (23I-4F) (U), WSRC-RP-94- 1217, Rev. 1, Westinghouse Savannah River Company, Aiken, South Carolina (includes the Baseline Risk Assessment).

WSRC (Westinghouse Savannah River Company), 1995b. Proposed Plan for the Burma Road Rubble Pit (23 l-4F) $(U)$, WSRC-RP-95- 1531, Rev. 1,
Westinghouse Savannah River Company, Aiken, South Carolina. 


\section{APPENDIX A}

RESPONSIVENESS SUMMARY 


\section{Responsiveness Summary}

The public comment period for the Burma Road Rubble Pit Proposed Plan began on January 10, 1996 and ended on February 8, 1996. There were no requests for a public meeting about the proposed action. Two comments were received. Specific comments and responses are found below.

\section{Public Comment \#1}

Phone Call

January 11, 1996

\section{Burma Road Comment (U)}

On January 11, 1996, Lee Poe, citizen, offered the following comment, for consideration and response, regarding the Proposed Plan for the Burma Road Rubble Pit (231 -4F).

"How much money has SRS spent, to date, on the characterization and remedial process for the Burma Road Rubble Pits?"

\section{Response to Public Comment \#1}

The costs for the BRRP characterization/assessment are estimated to be $\$ 1,780,791$. A breakdown of the costs by the investigation and assessment phases follow.

The associated cost for the investigation phase are estimated to be $\$ 1,576,325$. The activities associated with this phase consist of the following:

(1) Work Plan development and regulatory approval,

(2) Field characterization including data validation,

(3) RFI/RI/BRA Report development and regulatory approval, and

(4) Program management associated with these tasks.

The cost for the assessment phase is estimated to be $\$ 204,466$. The activities associated with this phase consist of the following:

(1) Initiation of a feasibility study,

(2) Proposed Plan development and approval,

(3) Record of Decision development and approval and,

(4) Program management associated with these tasks.

It should be noted that the feasibility study was initiated before SRS had received approval from the regulators to proceed with the no action proposed plan.

Although these costs may seem high for a no action unit, it should be noted that the BRRP was not initially a candidate for no action. SRS had to provide sufficient data in the RFI/RI Report and the Baseline Risk Assessment (BRA) in order to show the regulators that this should be a no action waste unit. Information regarding the types of waste that were encountered during characterization had to be placed in the RFI/RI Report. Based on the 
RFI/RI Report, the BRA determined that the only contamination in the waste unit soils was arsenic which was used before the SRS existed. The groundwater contamination that exists beneath the BRRP is the result of upgradient migration and a corrective action for the groundwater will be determined after an investigation on the upgradient migration sources. After all the information was presented to the regulators, a decision was made to proceed with the no action for the BRRP surface unit only.

Public Comment \#2

Phone Call

January 29, 1996

\section{Public Comment on Burma Road Proposed Plan (U)}

The following comment was offered by Lee Poe, citizen, on the Burma Road Proposed Plan.

"The risk discussion portion of this Proposed Plan is unclear and written in a manner that assumes the reader has a thorough understanding of the CERCLA process and risk methodology. Future Proposed Plans should more clearly explain the assumptions used in the risk assessment, as well as the real risk associated with the waste unit in terms that are easily understood by the reader. Risk numbers should be accompanied with units and an explanation of what these numbers mean, to make the documents less confusing and complex."

\section{Response to Public Comment \#2}

Section VI, Summary of Operable Unit Risks has been revised to list the assumptions used for the Current Land Use and Future Land Use Baseline Risk Assessment. This section has also been revised to more clearly state what the risk numbers mean. The revisions to the text are shown below:

p. 10-1st column

"...This means that one in ten thousand to one in one million people may develop cancer over a lifetime as a result of exposure to cancer-causing contaminants...."

P. 10- 2nd column through D. 11 - top of 2nd column

"In order to determine the carcinogenic (cancer) and non-carcinogenic hazards the following general exposure assumptions were used in the baseline risk assessment:

Current Land Use Scenario

Environmental Researcher

The adult environmental researcher receptor was assumed to enter onto the BRRP unit on an intermittent basis. The adult was assumed to work in the BRRP area for 72 days per year (approximately one quarter of the year). Exposures were evaluated for a short-term and longterm scenario (over a half-year and a 25 year interval, respectively). It was also assumed that the person would remain at the BRRP unit or in the BRRP vicinity for a four hour work period. 
The person would wear clothing which covers all bodily areas with the exception of the face, hands, and forearms.

\section{Future Land Use Scenarios}

\section{Residential Scenario}

The future residential adult receptor was assumed to reside on the BRRP for a long-term duration of 30 years and/era short-term duration of 5 years. It was anticipated that the adult residential person would engage in gardening/yard maintenance activities for a total of eight hours per week year-round (four two-hour periods per week, 350 days/year, assuming approximately two weeks spent away from the residence per year). During such activities, the person would wear clothing which covers all bodily areas with the exception of the face, arms, hands, and lower legs.

The future residential child receptor was assumed to reside on the BRRP between the ages of two through seven years. The child was assumed to live in a house constructed in close proximity tothe BRRP. The child would engage in outdoor activities 350 days/year (assuming approximately two weeks spent away from the residence per year). The average rate for time spent outdoors would encompass periods when exposures may be more or less frequent, as well as times when adverse weather would prohibit outdoor activity. It was assumed that the young child would remain outdoors for a four hour period.

\section{Occupational Worker}

The primary receptor examined under the future commercial use scenario was an on-site adult worker aged 18 years or older. Soil exposure could occur during normal day-to-day activities for an on-site worker.

\section{Environmental Researcher}

The adult environmental researcher receptor was assumed to enter onto the BRRP unit on an intermittent basis. The adult was assumed to work in the BRRP area for 72 days per year (approximately onequarter of the year). Exposures were evaluated forashort-term and longterm scenario (overa half-year and a25 year interval, respectively). It was also assumed that the person would remain at the BRRP unit or in the BRRP vicinity forafour hour work period. The person would wear clothing which covers all bodily areas with the exception of the face, hands, and forearms."

\section{P. 13- 1st column}

For the future residential adult, the only estimated risk from the unit soils was the ingestion of arsenic with a risk value of $1.9 \times 10^{-6}$ (i.e., there is a 1.9 in one million chance of developing cancer from the ingestion of arsenic). And, for the future residential child, the only estimated risk from the unit soils was the ingestion of arsenic with a risk value of $2.8 \times 10^{-6}$ (i.e., there is a 2.8 in one million chance of developing cancer from the ingestion of arsenic). 